\title{
The effect of gelatinization degree and source of starch on the ileal and faecal digestibility of nutrients and growth performance of early-weaned piglets $^{*}$
}

\author{
D. Kotara and B. Fuchs \\ Department of Animal Nutrition and Feed Quality, \\ Wroclaw Agricultural University \\ Chelmońskiego 38D, 51-639 Wroctaw, Poland
}

\begin{abstract}
This experiment was conducted to study the effect of degree of starch gelatinization and source in feeding early-weaned piglets. Nine diets were formulated on the basis of three cereals: hull-less barley, wheat, and maize, and three levels of starch gelatinization $(23.8,54.6$ and $81.9 \%)$ for each cereal. Cereal grains was processed by pelleting. On the seventh day after weaning, 36 piglets were killed to measure apparent ileal and faecal digestibility of the nutrients of experimental diets. The results of this experiment showed that growth performance and apparent ileal and faecal digestibility were affected by source of cereal and degree of starch gelatinization $(\mathrm{P}<0.01, \mathrm{P}<0.05)$. Better growth and the highest apparent ileal and faecal digestibility coefficients were observed when pigs were fed wheat-based diets that contained about $80 \%$ gelatinized starch.
\end{abstract}

KEY WORDS: hull-less barley, wheat, maize, starch gelatinization, digestibility, piglets

\section{INTRODUCTION}

A common practice in the pig industry is to decrease the age of weaning so as to increase sow productivity. However, by decreasing the weaning age to 21 days, piglets are often subject to a post-weaning growth reduction (Friesen et al.,

- Supported by the State Committee for Scientific Rescarch, No. 5 P06E 00519 
1993). The separation of the sow from the piglets changes the main energy source since the milk fat of the sow is replaced by carbohydrates (mainly starch) in the post-weaning diets (Van der Poel et al., 1990). Several studies have suggested that starch can be modified by different heat treatments that result in changes in its crystallinity and/or gelatinization (Van der Poel et al., 1989, 1990; Huang et al., 1997). Improvement of digestibility due to cereal processing in piglets has also been reported by other authors (Gdala et al., 1997; Medel et al., 2000). In contrast, Hongtrakul et al. (1998) observed little effect (for some nutrients) of degree of dietary starch gelatinization on digestibility.

The objective of this experiment was to investigate the effect of heat processing (pelleting) of various cereal grains (hull-less barley, wheat and maize) and the degree of starch gelatinization on apparent ileal and faecal digestibility and growth performance of early-weaned pigs.

\section{MATERIAL AND METHODS}

A total of 792 piglets (weaned on day 22 of age and initial body weight about $7 \mathrm{~kg}$ ) from 81 litters were used to study the effect of starch gelatinization in pelleting cereal on apparent ileal and faecal digestibility and growth performance of piglets. Nine treatments were arranged factorially with the main effects including carbohydrate source (hull-less barley, wheat and maize) and three levels of starch gelatinization $(23.8,54.6$ and $81.9 \%$ ) for each cereal. A cereal was pelleted once or twice (at temperatures from 85 to $90^{\circ} \mathrm{C}$ ) before including in the mixtures, and then all components were mixed and pelleted at a temperature under $70^{\circ} \mathrm{C}$.

Each treatment was replicated four times. After weaning, the pigs were assigned to groups of 22 in pens with slotted metal flooring. Each pen contained two self-feeders and three nipple waterers to provide ad libitum access to feed and water. The temperature was maintained at $30^{\circ} \mathrm{C}$ for the first week and then gradually reduced to a comfortable one for pigs. Pigs were fed complete diets from day 7 after birth to day 21 after weaning (Table 1). All diets contained $53.61 \%$ of their respective carbohydrate source, $16 \%$ milk powder, $9-10 \%$ dried whey, $8-10 \%$ soyabean protein concentrate (Soycomil), and $4-5 \%$ fish meal. Diets were formulated to contain $1.5 \%$ of total lysine; all other amino acids were included at a ratio relative to lysine (NRC, 1998). Chromium oxide $(0.20 \%)$ was used as a marker in the experimental diets.

Average feed intake (ADFI), average daily gain (ADG) and feed conversion ratio (FCR) were recorded weekly.

On day 7 after weaning, 36 piglets were killed three $h$ after the morning meal (4 piglets from each group). The gastrointestinal tract was rapidly taken off. 
TABLE 1

Composition and nutritive value of dicts, $\%$

\begin{tabular}{|c|c|c|c|}
\hline Item & Barley & Wheat & Maize \\
\hline Barley & 53.61 & - & - \\
\hline Wheat & - & 53.61 & - \\
\hline Maize & - & - & 53.61 \\
\hline Dried skim milk & 16.00 & 16.00 & 16.00 \\
\hline Dried whey & 10.00 & 10.00 & 9.00 \\
\hline Soyabean protein concentrate & 8.00 & 8.00 & 10.00 \\
\hline Fish meal & 5.00 & 5.00 & 4.00 \\
\hline Soyabean oil & 4.00 & 4.00 & 4.00 \\
\hline L-lysine & 0.35 & 0.35 & 0.35 \\
\hline Alimet (DL-methionine $78 \%$ ) & 0.28 & 0.28 & 0.28 \\
\hline L-threonine & 0.16 & 0.16 & 0.16 \\
\hline Vitamins and mineral premix ${ }^{a}$ & 0.50 & 0.50 & 0.50 \\
\hline Monocalcium phosphate & 0.50 & 0.50 & 0.50 \\
\hline Salt & 0.10 & 0.10 & 0.10 \\
\hline Calcium formate & 1.00 & 1.00 & 1.00 \\
\hline Zinc oxide & 0.30 & 0.30 & 0.30 \\
\hline Chromium oxide & 0.20 & 0.20 & 0.20 \\
\hline \multicolumn{4}{|l|}{ In $1 \mathrm{~kg}$} \\
\hline metabolizable energy, $\mathrm{MJ}$ & 14.59 & 14.27 & 14.31 \\
\hline crude protein, $g$ & 208 & 212 & 206 \\
\hline lysine, $g$ & 15.84 & 15.53 & 15.32 \\
\hline starch, g & 404 & 313 & 328 \\
\hline crude fibre, $g$ & 2.48 & 2.25 & 2.06 \\
\hline $\mathrm{NDF}, \mathrm{g}$ & 10.77 & 9.41 & 9.89 \\
\hline $\mathrm{Ca}$ & 9.11 & 9.32 & 9.12 \\
\hline total $\mathrm{P}$ & 6.94 & 7.01 & 6.91 \\
\hline
\end{tabular}

a mineral and vitamins composition for $1 \mathrm{~kg}$ of complete diets: vit. A, $15.000 \mathrm{IU}$; vit. $\mathrm{D}_{3}, 1.800 \mathrm{IU}$; vit. E, $30 \mathrm{IU}$; vit. K, $2 \mathrm{mg}$; thiamine, $1.4 \mathrm{mg}$; ribofiavin, $4.8 \mathrm{mg}$; pantothenic acid, $12 \mathrm{mg}$; niacin, $20 \mathrm{mg}$; pyridoxine, $3 \mathrm{mg}$; biotin, $160 \mu \mathrm{g}$; folic acid, $1.6 \mathrm{mg}$; cyanocobalamin, $36 \mu \mathrm{g}$; choline, $400 \mathrm{mg} ; \mathrm{Fe}, 100 \mathrm{mg}$; Cu, $180 \mathrm{mg}$; Mn, $110 \mathrm{mg}$ Z Zn, $100 \mathrm{mg}$; Co, $100 \mu \mathrm{g} ; \mathrm{Sc}, 300 \mu \mathrm{g} ; \mathrm{J}, 1.6 \mathrm{mg}$

Digesta from the ileum and rectum was taken, placed in clean plastic containers and stored at $-20^{\circ} \mathrm{C}$.

Feeds, ileum and rectum digesta were analyzed according to the methods of Van Soest et al. (1991) for NDF and (AOAC, 1990) for dry matter, nitrogen, ash, ether extract, starch, crude fibre. Starch gelatinization, as a proportion of total starch, was determined by enzymatic hydrolysis.

In the experiment, data were analyzed as a randomized complete bloc design in a $3 \times 3$ factorial arrangement. Analysis of variance was performed using the STATGRAPHICS program. 


\section{RESULTS}

Data on the influence of diet on performance of piglets are shown in Table 2. Feeding wheat-based diets resulted in a higher average daily gain (ADG) than feeding barley- or maize-based diets only in the first week after weaning (162 vs 143 and $144 \mathrm{~g} / \mathrm{d}, \mathrm{P}<0.05)$. Average daily feed intake (ADFI) $(175 \mathrm{vs} 160 \mathrm{~g} / \mathrm{d}$, $\mathrm{P}<0.05)$, and FCR $(1.10 \mathrm{vs} 1.20, \mathrm{P}<0.05)$ were affected more by wheat than barley. From days 7 to 14 and 14 to 21 post weaning, ADG, ADFI and FCR were similar among the three cereal diets. Unexpectedly, from day 14 to 21 we noted a significant difference in ADG between maize- and barley-based diets (484 vs $468 \mathrm{~g} / \mathrm{d}$, $\mathrm{P}<0.05$ ).

TABLE 2

Effect of dietary treatment on performance of piglets according to the period

\begin{tabular}{|c|c|c|c|c|c|c|c|}
\hline \multirow{2}{*}{ Item } & \multicolumn{3}{|c|}{ Cereal sources } & \multicolumn{3}{|c|}{ Starch gelatinization } & \multirow{2}{*}{ SEM } \\
\hline & barley & wheat & maize & $23.8 \%$ & $54.6 \%$ & $81.9 \%$ & \\
\hline \multicolumn{8}{|l|}{ Day 0 to 7} \\
\hline ADG, $\mathrm{g}$ & $143^{a}$ & $162^{b}$ & $144^{a}$ & $133^{a}$ & $144^{a}$ & $173^{\mathrm{b}}$ & 6.38 \\
\hline ADFI, $g$ & $160^{\mathrm{s}}$ & $175^{\circ}$ & $169^{\mathrm{ab}}$ & $160^{\mathrm{a}}$ & $170^{\mathrm{ab}}$ & $178^{\mathrm{b}}$ & 4.20 \\
\hline feed/gain & $1.16^{\mathrm{ab}}$ & $1.10^{\mathrm{b}}$ & $1.20^{\mathrm{s}}$ & $1.24^{\mathrm{B}}$ & $1.20^{\mathrm{B}}$ & $1.08^{\mathrm{A}}$ & 0.03 \\
\hline \multicolumn{8}{|l|}{ Day 7 to 14} \\
\hline ADG, $g$ & 354 & 361 & 353 & $338^{a}$ & $356^{\mathrm{ab}}$ & $373^{b}$ & 7.11 \\
\hline ADFI, $g$ & 454 & 456 & 448 & 446 & 452 & 460 & 5.88 \\
\hline feed/gain & 1.29 & 1.25 & 1.26 & 1.29 & 1.26 & 1.24 & 0.03 \\
\hline \multicolumn{8}{|c|}{ Day 14 to 21} \\
\hline ADG, $g$ & 365 & 379 & 386 & 365 & 376 & 390 & 9.41 \\
\hline ADFI, $\mathrm{g}$ & $468^{a}$ & $471^{\text {ab }}$ & $484^{b}$ & $468^{\mathrm{a}}$ & $471^{\mathrm{ab}}$ & $484^{b}$ & 4.87 \\
\hline feed/gain & 1.29 & 1.27 & 1.27 & $1.32^{\mathrm{a}}$ & $1.27^{\mathrm{ab}}$ & $1.23^{\mathrm{b}}$ & 0.028 \\
\hline
\end{tabular}

Increasing the degree of starch gelatinization in cereal increased ADG from day 0 to $7 \mathrm{~d}$ and 7 to 14 . Pigs fed diets containing $81.9 \%$ gelatinized starch had the greatest ADG $(173$ vs 144 and $133 \mathrm{~g} / \mathrm{d}, \mathrm{P}<0.05)$ than those fed diets containing 23.8 and $54.6 \%$ gelatinized starch in the first week after weaning. In the second period (from 7 to $14 \mathrm{~d}$ ) we observed that ADG also tended to be higher $(\mathbf{P}<0.05)$. The feed conversion ratio and ADFI were improved $(\mathrm{P}<0.05)$ during the first and the third week of the experiment.

The apparent ileal and faecal digestibility of various nutrients of the experimental diets are given in Table 3 . The total tract digestibility coefficients of ener- 
TABLE 3

Effect of dietary treatment on apparent ileal and faecal digestibility of dietary nutrients

\begin{tabular}{|c|c|c|c|c|c|c|c|}
\hline \multirow{2}{*}{ Item } & \multicolumn{3}{|c|}{ Cereal sources } & \multicolumn{3}{|c|}{ Starch gelatinization } & \multirow{2}{*}{ SEM } \\
\hline & barley & wheat & maize & $23.8 \%$ & $54.6 \%$ & $81.9 \%$ & \\
\hline \multicolumn{8}{|c|}{ Faecal digestibility } \\
\hline dry matter & 85.6 & 88.3 & 88.6 & $85.3^{\mathrm{a}}$ & $87.8^{\mathrm{ab}}$ & $89.5^{\mathrm{b}}$ & $1.0 \mathrm{I}$ \\
\hline organic matter & 85.2 & 87.6 & 86.9 & $84.6^{\mathrm{a}}$ & $86.6^{\mathrm{ab}}$ & $88.4^{b}$ & 0.99 \\
\hline energy & $85.5^{\mathrm{A}}$ & $89.5^{B}$ & $87.6^{\mathrm{C}}$ & $86.2^{\mathrm{A}}$ & $87.5^{\mathrm{B}}$ & $88.9^{c}$ & 0.58 \\
\hline crude protein & 84.9 & 85.1 & 86.6 & $83.0^{\mathrm{a}}$ & $86.2^{\mathrm{b}}$ & $87.4^{b}$ & 0.72 \\
\hline starch & $99.3^{a}$ & $99.5^{\mathrm{b}}$ & $99.1^{a}$ & $98.2^{\mathrm{As}}$ & $99.2^{\mathrm{Bb}}$ & $100^{\mathrm{Bc}}$ & 0.12 \\
\hline NDF & $64.1^{\mathrm{A}}$ & $70.2^{\mathrm{B}}$ & $70.3^{\mathrm{B}}$ & $64.7^{\mathrm{A}}$ & $68.8^{\mathrm{B}}$ & $71.1^{\mathrm{C}}$ & 1.02 \\
\hline \multicolumn{8}{|l|}{ Ileal digestibility } \\
\hline dry matter & $71.0^{a}$ & $72.2^{4}$ & $75.1^{\mathrm{b}}$ & $70.4^{a}$ & $73.4^{\mathrm{b}}$ & $74.3^{b}$ & 0.57 \\
\hline organic matter & $73.1^{\mathrm{a}}$ & $76.5^{\mathrm{b}}$ & $75.9^{\mathrm{b}}$ & $72.9^{\mathrm{Aa}}$ & $74.9^{\mathrm{Bb}}$ & $77.2^{\mathrm{Bc}}$ & 0.84 \\
\hline energy & $75.6^{\mathrm{a}}$ & $78.4^{\mathrm{b}}$ & $75.9^{4}$ & $75.2^{\mathrm{Aa}}$ & $77.6^{\mathrm{Bb}}$ & $79.0^{\mathrm{Bc}}$ & 0.56 \\
\hline crude protein & $73.1^{\mathrm{a}}$ & $76.5^{\mathrm{b}}$ & $76.5^{b}$ & $73.4^{a}$ & $75.4^{b}$ & $77.3^{\mathrm{b}}$ & 0.89 \\
\hline starch & $98.6^{\mathrm{B}}$ & $98.1^{\mathrm{B}}$ & $96.2^{\mathrm{A}}$ & $96.4^{\mathrm{A}}$ & $97.2^{\mathrm{B}}$ & $98.4^{\mathrm{C}}$ & 0.18 \\
\hline NDF & $28.3^{A}$ & $34.1^{\mathrm{B}}$ & $33.3^{B}$ & $24.1^{\text {Aa }}$ & $34.2^{\mathrm{Bb}}$ & $37.3^{B c}$ & 1.03 \\
\hline
\end{tabular}

$\mathrm{a}, \mathrm{b}-\mathrm{P}<0.05 ; \mathrm{A}, \mathrm{B}-\mathrm{P}<0.01$

gy, starch and NDF were higher for diets with wheat- or maize- than barley-based diets $(\mathrm{P}<0.01$ and $\mathrm{P}<0.05)$. Pigs fed the diets containing $81.9 \%$ gelatinized starch had greater apparent nutrient digestibilities than pigs fed diets containing 54.6 or $23.8 \%$ gelatinized starch.

Wheat- and maize-based diets also showed a higher apparent ileal digestibility than barley for analyzed nutrients. However, starch from barley and wheat was digested better than maize starch ( 98.1 and 98.6 vs $96.2 \%, \mathrm{P}<0.01$ ). Apparent ileal digestibility of diets with different degrees of starch gelatinization, showed that with increasing gelatinization, nutrient digestibility coefficients increased $(\mathrm{P}<0.01$, $\mathrm{P}<0.05$ ).

\section{DISCUSSION}

Cereal grains are the major energy source in diets for early-weaned piglets. About $60 \%$ of the energy ingested by weaned pigs is derived from carbohydrates contained in plant products. This feeding may not be optimal owing to problems in adaptation of the piglets' immature digestive system (Van der Poel et al., 1989). Insufficient secretion of $\alpha$-amylase (Lindemann et al., 1986) and the fact that starch is stored in plants in a crystalline complex structure might impair its digestion in 
pigs. According to Shields et al. (1980), amylase production by the pancreas increases progressively until the age of 10 weeks. Efrid et al. (1982) also reported an increase in amylase production. Recent studies have shown that heat processing can be applied to improve starch utilization by early-weaned piglets. Medel et al. (1999) found a positive effect in average daily gains (ADG) and average daily feed intake (ADFI) for in the first 2 weeks after weaning when extruded barley was used in the diet and a decrease when maize was fed. Similar results, decreased ADG and ADFI, were observed in the work of Hongtrakul et al. (1996) when pigs were fed maize-based diets. In contrast, our results showed that including pelleted wheat into diets improved (in the first week after weaning) ADG, ADF and feed conversion ratio in comparison with barley- or maize-based diets. However, pigs fed maize diets tended to have similar ADG, ADFI and feed conversion ratios to those fed barley diets. Medel et al. (1999) observed that processed maize causes a higher incidence of diarrhoea than processed barley, and hypothesized that processing might cause higher rates of feed intake after weaning, a situation that could induce overloading of the digestive tract and consequently diarrhoea. This hypothesis does not agree with our results, because we did not observe diarrhoea in any part of the experimental period.

Increasing starch gelatinization in maize decreased ADG and ADFI in an experiment by Hongtrakul et al. (1998). This authors suggested that these results may be explained by chemical changes of starch called retrogradation. Therefore, although gelatinization of starch increases the digestibility of carbohydrates, retrogradation decreases digestibility of starch in the small intestine. Bjorck et al. (1985) found that heat-processed maize had increased starch gelatinization, which improved the palatability and feed intake of the maize-based product. In our study, increasing the degree of starch gelatinization resulted in differences in ADG, ADFI, feed conversion and apparent ileal and faecal digestibility of the nutrients of experimental diets. In our previous research (Kotara and Fuchs, in press) we also observed that increasing the degree of starch gelatinization in wheat-barley-based diets improved apparent faecal digestibility coefficients of prestarter and starter diets.

However, in recent experiments, apparent ileal and faecal digestibility in the most processed cereal, including wheat, barley and maize was improved (Huang et al., 1997, 1998; Medel et al., 1999, 2000; Van der Poel et al., 1999). All cited results in this paper related to heat processing of cereal (extrusion, expanding, micronization) but pelleting was tested less. Johston et al. (1997) reported that weaned pigs fed pelleted diets had higher growth rates than pigs fed expanded diets. Mavromichalis and Baker (2000) found that pelleting of complete nursery pig diets had no influence on losses of lysine bioavailability.

In conclusion, in this experiment, pelleting of cereal grains had a beneficial effect on the degree of starch gelatinization, growth performance and apparent 
ileal and faecal digestibility of diets of early-weaned pigs. Therefore, the use of processed wheat or maize, especially containing about $80 \%$ gelatinized starch is recommended.

\section{REFERENCES}

AOAC, 1990. Official Methods of Analysis. Association of Official Analytical Chemists. $15^{\text {th }}$ Edition. Arlington, VA

Bjorck I., Matoba T., Nair B.M., 1985. In vitro enzymatic determination of the protein nutritional value and the amount of available lysine in extruded cereal based product. Agr. Biol. Chem. 49, 945-951

Efrid R.C., Amstrong W.D., Herman D.L., 1982. The development of digestive capacity in young pigs. Effects of age and weaning system. J. Anim. Sci. 55,1380-1387

Friesen K.G., Nelssen J.L., Goodband R.D., Behnke K.C., Kats L.J., 1993. The effect of moist extrusion of soy products on growth performance and nutrient utilization in the early-weaned pig. J. Anim. Sci. 71, 2099-2109

Gdala J., Johansen H.N., Bach-Knudsen K.E., Knap I.H., Wagner P., Jorgensen O.B., 1997. The digestibility of carbohydrates, protein and fat in the small and large intestine of piglets fed nonsupplemented and enzyme supplemented diets. Anim. Feed Sci. Tech. 65, 15-33

Hongtrakul K., Bergstrom J.R., Goodband R.D., Behnke K.C., Nessmith W.B., Tokach M.D., Nelssen J.L., 1996. The effect of carbohydrate source and extrusion processing on growth performance of segregated early-weaned pigs. J. Anim. Sci. 74, Suppl. 1, 169 (Abstr.)

Hongtrakul K., Goodband R.D., Behnke K.C., Nelssen J.L., Tokach M.D., Bregrestrom J.R., Nessmith W.B., Kim I.H., 1998. The effect of extrusion processing of carbohydrate source on weaning pig performance. J. Anim. Sci. 76, 3034-3042

Huang S.X., Sauer W.C., Pickard M., Li S., Hardin R.T., 1997. Effect of micronization on energy, starch and amino acid digestibilities in wheat for young pigs. J. Anim. Feed Sci. 6, 353-368

Huang S.X., Sauer W.C., Pickard M., Li S., Hardin R.T., 1998. Effect of micronization on energy, starch and amino acid digestibility in hulless barley for young pigs. Can. J. Anim. Sci. 78, 81-87

Johston S.L., Traylor L., Hines R.H., Hancock J.D., Behnke K.C., Sorrell S.P., 1997. Expander condition of complex nursery diets affects growth performance of weanling pigs. J. Anim. Sci. 75, Suppl. 1, 72 (Abstr.)

Kotara D., Fuchs B., 2001. The level of digestion main nutrients of diets for piglets depending on degree of starch gelatinization (in press)

Lindemann M., Cornelius S., El Kandelgy S., Moser R., Pettigrew J., 1986. Effect of age, weaning and diet on digestive enzyme levels in the piglet. J. Anim. Sci. 62, 1298-1307

Mavromichalis I., Baker D.H., 2000. Effects pelleting and storage of a complex nursery pig diet on lysine bioavailability. J. Anim. Sci. 78, 341-347

Medel P., Garcia M., Lázaro R., de Blas C., Mateos G.G., 2000. Particle size and heat treatment of barley in diets for early-weaned piglets. Anim. Feed Sci. Tech. 84, 13-21

Medel P., Salado S., de Blas J.C., Mateos G.G., 1999. Processed cereals in diets for early-weaned piglets. Anim. Feed Sci. Tech. 82, 145-156

NRC, 1998. Nutrient Requirements of Swine. $10^{\text {th }}$ Edition. National Academy Press, Washington, DC Shields R.G., Ekstron K.E., Mahan D.C., 1980. Effect of weaning age and feeding method on digestive enzyme development in swine from birth to ten weeks. J. Anim. Sci. 50, 257-265 
Van der Poel A.F.B., Den Hartog L.A., Van den Stiphout W.A.A., Bremmers R, Huisman J., 1990. Effects of extrusion of maize on ileal and faecal digestibility of nutrients and performance of young piglets. Anim. Feed Sci. Tech. 29, 309-320

Van der Poel A.F.B., Den Hartog L.A., Van den Abeele TH., Boer H., Van Zulichem D.J., 1989. Effect of infrared irradiation or extrusion processing of maize on its digestibility in piglets. Anim. Feed Sci. Tech. 26, 29-43

Van Soest P.J., Robertson J.B., Lewis B.A., 1991. Carbohydrate methodology, metabolism, neutral detergent fibre and non-starch polysaccharides in relation to animal nutrition. J. Dairy Sci. 74, 3583-3597

\section{STRESZCZENIE}

Wplyw stopnia skleikowania i źródła skrobi na strawność jelitową i ogólną składników pokarmowych oraz wzrost weześnie odlączonych prosiąt

Wykonano dziewięć mieszanek opartych na łuskanym jęczmieniu, pszenicy albo kukurydzy, które przed wprowadzeniem do mieszanck poddano procesowi granulacji i uzyskano odpowiednio 23,8 ; 54,6 i $81,9 \%$ skleikowania skrobi. W 7 dniu po odsadzeniu poddano ubojowi 36 prosiąt w celu określenia strawności do końca jelita cienkicgo i do końca przewodu pokarmowego podstawowych składników mieszanek. W badaniach stwierdzono, że zarówno rodzaj zboża, jak też stopień skleikowania skrobi w nich zawartej miał istotny $(\mathrm{P}<0,01, \mathrm{P}<0,05)$ wpływ na tempo wzrostu oraz strawność jelitową i strawność do końca przewodu pokarmowego podstawowych składników pokarmowych mieszanek. Najlepsze wyniki uzyskano, gdy do paszy dla prosiąt wprowadzono pszenice, a stopien skleikowania skrobi wynosil około $80 \%$. 